\title{
TULEVAISUUS ILMAN KIRJASTOJA JA KULTAMUNIA MUNIVAT KIRJASTOT
}

Suomen tieteellisen kirjastoseuran marraskuinen verkkoseminaari tarjosi monisyistä pohdittavaa ja käytännön vinkkejä kirjastojen markkinointiin ja viestintään liittyen. Tilaisuuden pääpuhujat, professori Alf Rehn ja kirjastokonsultointia tekevä Zuzana Helinsky, lähestyivät kirjastomarkkinointia hyvin eri näkökulmista. Toisaalta puheenvuorot leikkasivat samoja ennakkoluulottoman arvioinnin, kokeiluihin uskaltautumisen ja kirjastotoiminnan vaikuttavuuden teemoja, jotka tarjoavat visioinnin ja suunnittelun lähtöpisteitä erilaisille organisaatioille.

$\mathrm{T}$ aistelu huomiosta pakottaa tieteelliset kirjastot ja tietopalvelut miettimään, miten tavoittaa tehokkaasti palveluiden käyttäjät. Tavoitteena ei ole vain informoida tarjolla olevista palveluista, vaan rakentaa myös kuvaa kirjastosta ja tietopalvelusta toimijana tässä ajassa ja tulevaisuudessa.

Tähän tapaan voisi tiivistää Suomen tieteellisen kirjastoseuran marraskuisen verkkoseminaarin antia. Kirjasto kumppanina - viestinnän onnistumisia ja epäonnistumisia -seminaarissa olivat puhumassa professori Alf Rehn (Syddansk Universitet) ja kirjastojen markkinoinnista kirjoittanut Zuzana Helinsky (zh consulting). Kommenttipuheenvuoron Rehnin esitykseen esitti Vaasan Tritonia-tiedekirjaston johtaja ja Suomen yliopistokirjastojen verkoston puheenjohtaja Anne Lehto ja Helinskyn esityk- seen kirjastonjohtaja Heli Kautonen Suomalaisen Kirjallisuuden Seurasta. Seminaariiin osallistui 66 kirjastoalan ammattilaista.

Muutos ei ole takanapäin

Kirjastoissa ja kirjastoalan opinnoissa on jo pitkään mietitty kirjaston identiteettiin liittyviä kysymyksiä. Yritysten parissa paljon työskennellyt professori Alf Rehn toi tähän keskusteluun oman näkökulmansa esityksessään Kirjasto kuin lastu lainehilla? Tiedon viestinnän vaaralliset tulevaisuudet. Hänen mukaansa olennaista on katsoa ulos, sillä ajassa vaikuttavat trendit muokkaavat sitä ympäristöä, jossa

kirjasto toimii.

"Ei vain kirjastojen, vaan myös tietoon liittyvä toiminta on muuttumassa - ja ehkä jopa

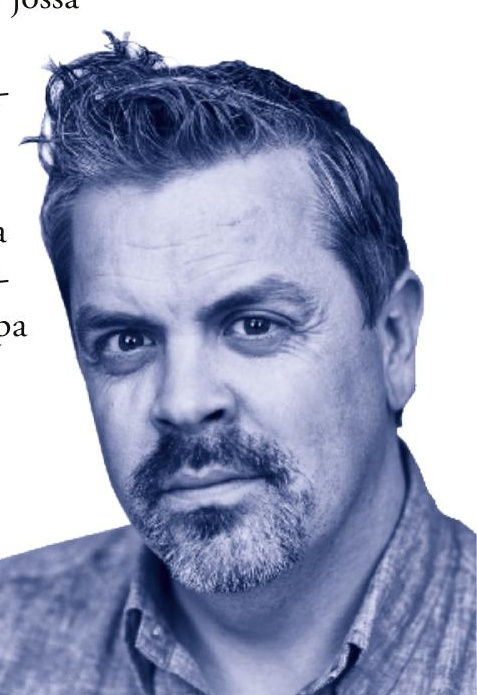


radikaalimmin kuin kuvittelemme. Olemme taipuvaisia ajattelemaan, että olemme jo nähneet muutoksen, että se on takanapäin”, Rehn toteaa ja jatkaa ajankohtaisella esimerkillä:

"Ihmiset ovat puhuneet koronapandemiasta dramaattisin sanoin. On sanottu, että se on musta joutsen, jotain ennenkuulumatonta. Tämä kaikki on täyttä roskaa: ei tämä ollut mikään musta joutsen. Tämä oli asia, miltei itsestäänselvyys, josta tiesimme 20 vuotta, mutta jolle emme tehneet mitään. Uskon, että on enemmänkin tällaisia asioita, joiden näemme tapahtuvan, mutta joita emme ota huomioon.”

Nykyistä tietoyhteiskuntaa Rehn kuvaa "aallokkona", jossa tiedon saanti, määrä, ymmärrys ja jopa tiedon käsite on muutoksessa. Nettitrollit ja salaliittoteoriat taivuttelevat tietoa omien tarkoitusten ajamiseen, mutta taistelua tiedosta käydään myös arkisemmin, erityisesti algoritmien tasolla.

"Kyse on siitä, miten paljon algoritmit jo nyt ohjaavat tietokäyttäytymistämme ja miten tämä tulee tulevassa tekoälyn aikakaudessa kärjistymään vielä enemmän. Kiinnostavaa on kysyä, mikä rooli tiedekirjastoilla on tässä.”

\section{Mikä on kirjaston tarina?}

Jokaisella on oma kuvansa kirjastosta: kirjasto on kokoelmat, se on mahdollisuus saada tietoa tai se on tuttu kirjastonhoitaja. Tässä tullaan Rehnin mukaan seminaarin varsinaiseen teemaan, markkinointiin ja viestintään.

"Kirjastot kertovat yleensä hyvin mielellään uusista projekteista ja uusista palveluista. Kun olemme kertoneet, mitä teemme, olemme markkinoineet ja tehneet viestintää. Tämä on ymmärrettävä mutta hyvin rajallinen tapa ymmärtää viestintä tässä päivässä. Viestintä ei ole vain sitä, että jaamme informaatiota toiminnastamme, vaan sitä, että luomme kuvaa itsestämme, kerromme tarinaa, jossa meillä on selkeä kuva siitä, kuka vie sitä eteenpäin ja kuka sitä kertoo. Tarina alkaa aina siitä, että sinulla on kuva siitä, kuka haluat olla ja mikä on se asema, jonka haluat vallata."

Rehnin mukaan yritysten markkinointi on nykyään tätä. Ne kertovat, mitä ne haluavat olla - suunnannäyttäjiä, vallankumouksellisia vai arvokkaita ja luotettavia.

Rehnillä ei ole tietenkään vastausta, mitä kirjastojen tulisi olla, mutta pitkin esitystään hän hahmottelee eri rooleja: Peesaaja pyrkii seuraamaan tutkijan tarpeita ja tekemään sen mukaan - "nöyryys voi olla näinä päivinä hyve". Johtaja tietää, mitä tässä ajassa tarvitaan - "tiedämme, koska meillä on nämä kokoelmat, tekniikat, informaatio ja metriikat”. Metsästäjä hakeutuu aktiivisesti asiakkaidensa pariin ja kertoo parhaat vinkit. Informaatiokuraattori kokoaa olemassa olevaa tietoa kiinnostavilla uusilla tavoilla.

Rehnillä on myös suosikkikirjastonsa, Wunderkammer, lapsuuden kirjasto, josta tiesi löytävänsä ihmeellisiä asioita.

"Kovasti toivon, että jotain tällaista - yllättävää, omituista, leikkisää - voi- 
si löytyä jälleen. Ulkona markkinoilla on aidosti toive tällaiselle kirjastolle."

"Vai olisiko kirjasto jotain aivan muuta? Pitäisikö kirjaston radikaalisti uudelleenmääritellä itsensä, tavalla, joka rikkoisi sitä kuvaa, joka kirjastosta on aiemmin ollut?"

\section{Entä jos kirjastoa ei ole?}

Mitä pitemmälle Rehnin esitys etenee, sitä enemmän hän siirtää vastuuta kuulijalle. Rehn alleviivaa epävarmuutta toteamalla, että hän "ei tiedä tulevaisuudesta yhtään mitään" ja että "kukaan ei tiedä, mitä on tulevaisuuden hyvä viestintä kirjastoille".

"Yhteiskunnassa, jossa teknologia oikeasti ja radikaalisti tulee muuttamaan sitä, miten teemme työmme, kirjaston on käytävä syvällistä keskustelua siitä, mitä kaikkea se voi olla tulevaisuudessa. Uuden ajan myötä tulevat aina uudet kyvykkyydet. Ne toimijat, jotka ottavat niistä mahdollisimman nopeasti kopin, ovat niitä, jotka pärjäävät parhaiten."

"Tarvitaanko tulevaisuudessa kirjastoja? Se kylmä tunne, joka teitä nyt kouraisi, on se tärkeä kysymys. On tärkeää katsoa aidosti kaikkia mahdollisia tulevaisuuksia, mukaan lukien sitä, jossa kirjastoja ei enää ole. Miksi? Koska ainoastaan tätä kautta voimme alkaa käydä kehittävää, reflektoivaa keskustelua, jossa mietitään niitä kyvykkyyksiä, jotka pakottavat meidät saman toistamiseen, ja niitä kyvykkyyksiä, jotka voivat uudelleen määritellä sen, mitä tiedekirjasto voi olla."
Hyvien käytäntöjen rinnalle tarvitaan myös kokeiluja.

"Kaikkein tärkeintä markkinoinnissa ja viestinnässä on nöyryys sen edessä, ettemme tiedä oikeaa tapaa. Ainoa, mitä voidaan tehdä on nöyrästi kokeilla."

\section{"Tärkeintä on: Tee se"}

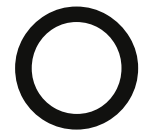
maa kirjastoalan konsulttifirmaa Ruotsissa pyörittävä Zuzana Helinsky lähestyi markkinointiteemaa Rehniä arkisemmasta ja käytännönläheisemmästä näkökulmasta, mutta yhteisiä leikkauspisteitäkin oli. Rehnin kannustaessa nöyrään kokeiluun Helinskyn pääviesti oli tekemisen, kokeilemisen, arvioimisen sinnikäs vuorottelu.

"Tärkeintä on: Tee se. On toistettava uudelleen ja uudelleen. Ei riitä, että munii kultamunia - niistä on myös kaakatettava (quackle)", Helinsky sanoi esityksensä päätteeksi.

Rehnin kääntäessä viestinnän huomiota pois niistä palveluista, joita kirjasto tällä hetkellä tarjoaa, Helinsky paneutui kaikella pieteetillä juuri niihin - tulevia palveluita unohtamatta.

"Meillä on kirjastoissa paljon tarjottavaa, josta asiakkaat eivät tiedä. Tähän tarvitsemme markkinointia. Markkinointia on sen kertomista, mitä on tarjottavana - se ei ole sen monimutkaisempaa", Helinsky totesi.

Helinskyn esityksen perustana oli hänen vuonna 20 I I ruotsiksi ilmestynyt teos, Pieni mutta tärkeä kirja kirjastojen markkinoinnista, joka on 
suomennettu 20 I 2. Alkuun Helinsky listasi kirjastomarkkinoinnin vaatimat perusasiat: rohkeus, sitkeys, näkyvyys ja oikeissa paikoissa - fyysisissä tai virtuaalisissa - oleminen.

"Kirjastolaiset eivät halua epäonnistua, mutta markkinoinnissa epäonnistumisia tulee. Eikä siinä mitään, sitten tehdään joko uudelleen tai toisella tavalla."

Esityksen - Marketing to get better mileage from your library resources varsinaisen ytimen muodostivat markkinoinnin vaiheiden läpikäyminen. Näitä ovat (I) analyysi eli nykytilanteen kartoitus ("how things are?"), (2) strategia ja suunnittelu eli priorisointi ("what to market?"), (3) taktiikka eli käytännön toteutus ("to whom, when and how to market?") ja (4) palaute eli opitun dokumentointi ("what is good, what is not good?").

\section{Analyysi tehtävä ainakin kerran vuodessa}

Analyysivaiheessa Helinsky korostaa rehellisyyttä tosiasioiden suhteen. Tätä voi ehkä verrata Rehnin "kylmiä tunteita" aiheuttaviin kysymyksiin.

"On kysyttävä, miten asiat ovat juuri nyt eikä miten toivomme niiden olevan. Miten näemme kirjaston?”

Helinskyn mukaan kirjastolaisten käyttöön soveltuvat useat tutut analyysimallit, kuten PEST (Political, Economic, Social, Technological), Five Forces Analysis ja swot (Strengths, Weaknesses, Opportunities, Threats).

"Analyysiin voi käyttää mitä ta- hansa analyysivälinettä. Käytän itse swotia, koska se on yksinkertainen. Esimerkiksi uusi teknologia voi olla kirjaston heikkous, jos emme tunne sitä, mutta se voi olla myös mahdollisuus. On hyvä listata uhat, koska kirjoittamalla ne ylös, ne eivät tunnu niin vaarallisilta. Analyysi on tehtävä vähintään kerran vuodessa, koska toimintaympäristö muuttuu."

\section{Strategiassa erotellaan tähdet} ja lemmikit

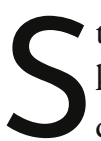

trategia on valintojen tekemistä, koska kaikkea voida markkinoida samaan aikaan. Esityksessään Helinsky käy läpi erityisesti Bostonin matriisia, joka tarkastelee palveluita nykyisten ja tulevien tarpeiden - eli markkinoiden - kannalta. Siihen kirjataan kaikki tuotteet ja palvelut, ja ne jaetaan tähtiin (stars), lypsylehmiin (cash cows), kysymysmerkkeihin (question marks) ja lemmikeihin (pets).

"Tähdet ovat helppo markkinoitava. Yliopistokirjastoissa tyypillisiä tähtiä ovat kurssit, työpajat, e-lehdet. Tähtien arvioiminen on hyvä tehdä yhdessä kollegoiden kanssa, koska jokaisella on luultavasti vähän erilainen näkemys tähdistä. Se on hyvä keskustelunaihe."

"Lypsylehmistä kirjasto tunnetaan, esimerkiksi yliopistokirjastot tunnetaan sähköisistä kokoelmista. Tietenkin tämä vaihtelee kirjastoittain ja muuttuu ajan myötä."

"On oltavia myös muutamia kysymysmerkkiä, koska ne pitävät yllä

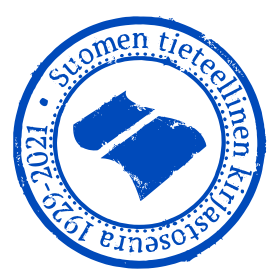


Alf Rehn:

Kirjasto kuin lastu lainehilla? Tiedon viestinnän vaaralliset tulevaisuudet.

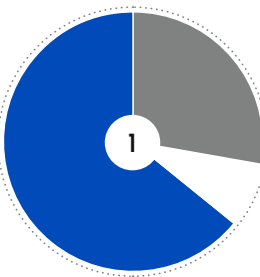

25 vastausta
Zuzana Halinsky: Marketing to get better mileage from your library resources.

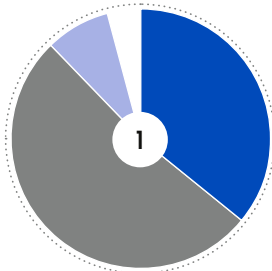

25 vastausta

Seminaarissa ehdotettiin säännöllistä keskustelutapaamista kirjastojen markkinoinnista ja tulevaisuudesta. Olisitko kiinnostunut osallistumaan sellaiseen, jos STKS kokeilee tilaisuuden organisoimista.

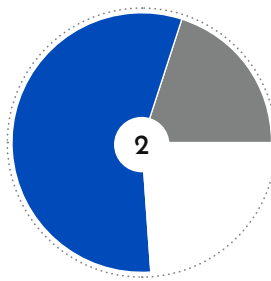

25 vastausta

\section{0

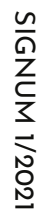

Kuva 1. Pääpuhujien esitykset samoin kuin kommenttipuheenvuorot saivat hyvää palautetta osallistujilta. Alf Rehnin esityksen ajatuksista arveli hyötyvänsä 92 prosenttia vastaajista, Zuzana Helinskyn esityksestä 88 prosenttia.

Kuva 2. Ajatus kirjaston markkinointiteeman jatkamisesta säännöllisissä tapaamisissa sai vastakaikua verkkoseminaarin osallitujilta.
Haluan hyödyntää työssäni

Sain ideoita ja tarvitsen ehkä työssäni

Ei ole tarpeellinen itselleni

En osaa sanoa

kehitystä. Emme tiedä, miten kysymysmerkit kehittyvät ja yleensä ne vievät paljon aikaa - tämän takia niitä ei voi olla liikaa. Kysymysmerkit voivat olla esimerkiksi uusia teknologioita."

Vaikein pala ovat lemmikit. Ne ovat palveluja, joista pitäisi luopua.

"Kirjastossa saattaa olla aivan eri näkemyksiä lemmikeistä, koska osa kollegoista on saattanut olla laittamassa alkuun jotain palvelua. Keskustelu on tässä todella olennaista. Lemmikkien löytäminen ei ole helppoa, mutta se on erittäin tärkeää, ja se maksaa vaivan - sitä kautta saadaan aikaa uusille palveluille.”

\section{Toteuttamisesta palautteen kautta uuteen alkuun}

Kun on päästy käsitykseen, mitä markkinoidaan, siirrytään toteutukseen.

"Tämä on kaikkein tärkein vaihe. On tärkeää sitouttaa mahdollisimman paljon henkilökuntaa mukaan markkinointiin. Kaikki organisaatiossa eivät ole suoraan tekemisissä asiakkaiden kanssa, mutta tekevät sen mahdolliseksi muille. Olemme usein hyviä ulkoisessa markkinoinnissa, mutta unohdamme sisäisen markkinoinnin.”
Markkinointi tapahtuu erilaisten viestintäkanavien kautta. Helinskyn lista on kattava: uutiskirjeet, sähköpostialertit, sähköpostiviestit, koulutustilaisuudet (kurssit, työpajat), kirjaston tapahtumat, yliopiston tapahtumat, hallinnon tilaisuudet, epäviralliset kohtaamiset ja keskustelut, kirjaston verkkosivut, intranet, yliopiston verkkosivut, virkistystilaisuudet, palveluluettelot, kokoelmakuvaukset, kirjaston tai yliopiston julkaisut, flyerit, chatit, botit...

"Moni kirjasto hyödyntää erittäin hyvin yliopiston tapahtumia kirjaston ja sen palveluiden markkinointiin. Viestinnän avain on se, että meillä on hyvä käsitys siitä, mitä ympärillämme tapahtuu."

Lopulta, kun on tehty ja kokeiltu, voidaan kysyä, miten meni. Palaute vaatii oman työnsä.

"Ensinnäkin, meidän on kannustettava ja pyydettävä asiakkaita antamaan palautetta. Kirjaston on kysyttävä ja pyydettävä palautetta. Ei kannata odottaa asiakkaiden tekevän sitä itse.”

JuUso Ala-Kyyny

Helsingin yliopiston kirjasto juuso.ala-kyyny@helsinki.fi 